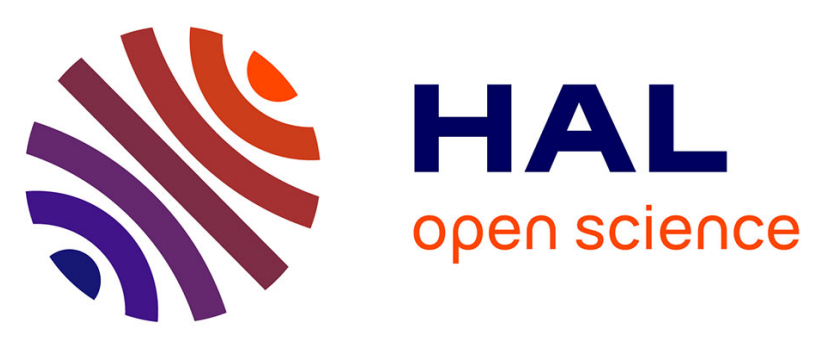

\title{
The pharmacokinetic interaction between mycophenolic acid and cyclosporine revisited: a commentary on "Mycophenolic acid glucuronide is transported by multidrug resistance-associated protein 2 and this transport is not inhibited by cyclosporine, tacrolimus or sirolimus". \\ Nicolas Picard
}

\section{- To cite this version:}

Nicolas Picard. The pharmacokinetic interaction between mycophenolic acid and cyclosporine revisited: a commentary on "Mycophenolic acid glucuronide is transported by multidrug resistanceassociated protein 2 and this transport is not inhibited by cyclosporine, tacrolimus or sirolimus".. Xenobiotica, 2013, 43 (9), pp.836-8. 10.3109/00498254.2012.761742 . inserm-00767689

\section{HAL Id: inserm-00767689 https://www.hal.inserm.fr/inserm-00767689}

Submitted on 16 May 2014

HAL is a multi-disciplinary open access archive for the deposit and dissemination of scientific research documents, whether they are published or not. The documents may come from teaching and research institutions in France or abroad, or from public or private research centers.
L'archive ouverte pluridisciplinaire HAL, est destinée au dépôt et à la diffusion de documents scientifiques de niveau recherche, publiés ou non, émanant des établissements d'enseignement et de recherche français ou étrangers, des laboratoires publics ou privés. 
The pharmacokinetic interaction between mycophenolic acid and cyclosporine revisited: a commentary on "Mycophenolic acid glucuronide is transported by multidrug resistanceassociated protein 2 and this transport is not inhibited by cyclosporine, tacrolimus or sirolimus".

Nicolas PICARD ${ }^{1,2,3}$

${ }^{1}$ INSERM, UMR-S850, Limoges, France; ${ }^{2}$ CHU Limoges, Department of Pharmacology and Toxicology, Limoges, France; ${ }^{3}$ Univ Limoges, Laboratory of Medical Pharmacology, Limoges, France.

\section{Address correspondence to:}

Nicolas Picard

Faculté de Médecine et de Pharmacie, Inserm UMR-S850

2 rue du Docteur Marcland

87025 Limoges cedex, France

Tel.: +33 5554359 70; fax: +33 5554359 36. E-mail address: nicolas.picard@ unilim.fr

Keywords: transporters; drug-drug interaction; enterohepatic cycling; Organic AnionTransporting Polypeptides. 
In the past 10 years, mycophenolic acid (MPA) has become a cornerstone agent in immunosuppressive therapy. Since the earliest pharmacokinetic studies, the crucial role of its glucuronidation has been highlighted (Bullingham et al., 1998). MPA is extensively metabolized to its inactive hydroxy- $\beta$-glucuronide (MPA-phenyl-glucuronide; MPAG) and the metabolite contributes to mycophenolic acid enterohepatic circulation after deglucuronidation in the gut. This feature is important since it accounts for $10 \%$ to $61 \%$ of total MPA exposure (Bullingham et al., 1998). It is usually reflected as a second increase in the MPA time concentration curve, occurring 6 to 12 hours after oral dosing. Clinically relevant differences in drug exposure depending on the calcineurin inhibitor (cyclosporine A or tacrolimus) given with mycophenolate mofetil (MMF) were described and attributed to an interaction with MPA enterohepatic cycling. The combination of MMF with tacrolimus as compared to cyclosporine in renal transplant recipients was found to give rise to higher residual concentrations and Area Under the Concentration curves (AUC) of MPA (Hubner et al., 1999, Zucker et al., 1997). Additional studies including a "control" group of patients receiving MMF without a calcineurin inhibitor suggested that cyclosporine but not tacrolimus is responsible for the interaction (Pou et al., 2001, Smak Gregoor et al., 1999). This was further demonstrated in Lewis rats: animals receiving MPA with cyclosporine showed a lower exposure to MPA, higher levels of MPAG, and less second MPA peak attributable to enterohepatic drug recirculation as compared to rats receiving MPA alone or with tacrolimus (van Gelder et al., 2001).

The hypothesis most often put forward is that cyclosporine decreases the biliary excretion of MPAG and thus the extent of enterohepatic recirculation. Evidence that this effect might result from the inhibition of the Multidrug Resistance-associated Protein 2 (MRP2) came from studies conducted in specific strands of rats deficient for the canalicular transporter (Hesselink et al., 2005, Kobayashi et al., 2004, Westley et al., 2006) but this has never been 
verified using a human model until now. In addition, cyclosporine was also found to result in lower plasma MPA/MPAG AUC ratio in mrp2-deficient rats, which suggests that mrp2independent mechanisms may be involved in this interaction (Hesselink et al., 2005).

In their article entitled "Mycophenolic acid glucuronide is transported by multidrug resistance-associated protein 2 and this transport is not inhibited by cyclosporine, tacrolimus or sirolimus", Patel et al. are the first group to study the interaction of cyclosporine on MPA enterohepatic cycling using in vitro models expressing human (and not rodent) MRP2 (Patel et al., 2012). They confirmed that MPAG is a substrate for the human transporter and showed for the first time that cyclosporine does not inhibit the activity of the transporter expressed in SF9 membrane vesicles. Based on results obtained using Madin-Darby Canine Kidney (MDCK) Cells transfected with MRP2, the authors suggest that cyclosporine would inhibit the uptake of MPAG at the basolateral membrane rather than its efflux by MRP2.

Using HEK293-transfected cells, we recently found that MPAG is a substrate for the Organic Anion Transporting Polypeptide (OATP) 1B3 and 1B1 (Picard et al., 2010), two uptake transporters specifically expressed at the basolateral membrane of hepatocytes. These transporters are thus likely to be involved in the interaction between MPA and cyclosporine. Consistent with this hypothesis, cyclosporine was reported as a potent inhibitor of both OATP1B1 and OATP1B3 in several in vitro studies (Shitara et al., 2003, Shitara et al., 2012, Treiber et al., 2007). It was also demonstrated that tacrolimus has less inhibitory effect on these transporters than cyclosporine. The concentration of tacrolimus to produce $50 \%$ inhibition $\left(\mathrm{IC}_{50}\right)$ of OATP activities is higher than $1 \mu \mathrm{M}$, while that of cyclosporine is within 0.1-1 $\mu \mathrm{M}$ (Fehrenbach et al., 2003, Shitara et al., 2012). Specifically regarding the OATP1B3mediated uptake of MPAG, we found that $1 \mu \mathrm{M}$ cyclosporine resulted in almost complete inhibition of uptake in transfected cells $(94 \pm 11 \%)$ whereas the same concentration of tacrolimus had almost no effect (9 $\pm 16 \%$ inhibition) (Picard et al., 2011). Interestingly 
enough, Shitara et al. (2012) showed that cyclosporine but not tacrolimus has a long-lasting inhibitory effect on OATP1B1 and OATP1B3 activities using transfected cells as well as using human hepatocytes (Shitara et al., 2012). These different inhibitory capabilities, as well as the fact that cyclosporine therapeutic blood levels are substantially higher than those of tacrolimus would explain that cyclosporine but not tacrolimus resulted in increase exposure to MPA in clinical settings.

The different effect of tacrolimus and cyclosporine on OATPs is also consistent with other reports on drug-drug interactions. This interaction between cyclosporine and cerivastatin has been essentially ascribed to the inhibition of active hepatic uptake by OATPs (Shitara et al., 2003). No interaction was described between this drug and tacrolimus (Lemahieu et al., 2005). The significant interaction between the endothelin receptor antagonist bosentan and cyclosporine was also entirely attributed to the inhibition of OATP transporters by cyclosporine (Treiber et al., 2007) and no interaction was reported in the case of tacrolimus.

Based on these data and the evidence provided by Patel et al., we suggest that drug-drug interaction between cyclosporine and MPA, initially attributed to MRP2 inhibition is due to the inhibition of MPAG-mediated uptake in hepatocytes by OATPs.

This leads to a reinterpretation of MPA hepatic disposition: after production in hepatocytes, MPAG is partly excreted into bile but also presumably transported into the blood sinusoids by active transporters to be further eliminated by the kidneys (the major elimination pathway of the metabolite). Circulating MPAG can secondarily be taken back up into hepatocytes by OATPs to be eliminated through the bile (Figure 1). Cyclosporine interacts with this transport by inhibiting OATPs in a greater extent than tacrolimus does.

On the other hand, renal elimination of MPAG involves an active uptake of the metabolite by the organic anion transporter 3 (OAT3; SLC22A8), located at the basolateral side of proximal tubular cells (Uwai et al., 2007, Wolff et al., 2007), followed by an apically-directed efflux in 
urine, presumably by MRP2 which was found to be expressed at this level (Schaub et al., 1999). This process has not been reported to be inhibited by calcineurin inhibitors.

OATP transporters should be considered for the future evaluation of drug-drug interaction with MPA. It is likely that these transporters play a significant role in the entero-hepatic cycling of other drugs.

\section{Declaration of interest}

The author has no conflict of interest to report. 


\section{References}

Bullingham RE, Nicholls AJ, Kamm BR. (1998). Clinical pharmacokinetics of mycophenolate mofetil. Clin Pharmacokinet, 34, 429-55.

Fehrenbach T, Cui Y, Faulstich H, Keppler D. (2003). Characterization of the transport of the bicyclic peptide phalloidin by human hepatic transport proteins. Naunyn Schmiedebergs Arch Pharmacol, 368, 415-20.

Hesselink DA, van Hest RM, Mathot RA, Bonthuis F, Weimar W, de Bruin RW, van Gelder T. (2005). Cyclosporine interacts with mycophenolic acid by inhibiting the multidrug resistance-associated protein 2. Am J Transplant, 5, 987-94.

Hubner GI, Eismann R, Sziegoleit W. (1999). Drug interaction between mycophenolate mofetil and tacrolimus detectable within therapeutic mycophenolic acid monitoring in renal transplant patients. Ther Drug Monit, 21, 536-9.

Kobayashi M, Saitoh H, Kobayashi M, Tadano K, Takahashi Y, Hirano T. (2004). Cyclosporin A, but not tacrolimus, inhibits the biliary excretion of mycophenolic acid glucuronide possibly mediated by multidrug resistance-associated protein 2 in rats. $\mathrm{J}$ Pharmacol Exp Ther, 309, 1029-35.

Lemahieu WP, Hermann M, Asberg A, Verbeke K, Holdaas H, Vanrenterghem Y, Maes BD. (2005). Combined therapy with atorvastatin and calcineurin inhibitors: no interactions with tacrolimus. Am J Transplant, 5, 2236-43.

Patel CG, Ogasawara K, Akhlaghi F. (2012). Mycophenolic acid glucuronide is transported by multidrug resistance-associated protein 2 and this transport is not inhibited by cyclosporine, tacrolimus or sirolimus. Xenobiotica.

Picard N, Levoir L, Lamoureux F, Yee SW, Giacomini KM, Marquet P. (2011). Interaction of sirolimus and everolimus with hepatic and intestinal organic anion-transporting polypeptide transporters. Xenobiotica, 41, 752-7. 
Picard N, Yee SW, Woillard JB, Lebranchu Y, Le Meur Y, Giacomini KM, Marquet P. (2010). The role of organic anion-transporting polypeptides and their common genetic variants in mycophenolic acid pharmacokinetics. Clin Pharmacol Ther, 87, 100-8.

Pou L, Brunet M, Cantarell C, Vidal E, Oppenheimer F, Monforte V, Vilardell J, Roman A, Martorell J, Capdevila L. (2001). Mycophenolic acid plasma concentrations: influence of comedication. Ther Drug Monit, 23, 35-8.

Schaub TP, Kartenbeck J, Konig J, Spring H, Dorsam J, Staehler G, Storkel S, Thon WF, Keppler D. (1999). Expression of the MRP2 gene-encoded conjugate export pump in human kidney proximal tubules and in renal cell carcinoma. J Am Soc Nephrol, 10, 1159-69.

Shitara Y, Itoh T, Sato H, Li AP, Sugiyama Y. (2003). Inhibition of transporter-mediated hepatic uptake as a mechanism for drug-drug interaction between cerivastatin and cyclosporin A. J Pharmacol Exp Ther, 304, 610-6.

Shitara Y, Takeuchi K, Nagamatsu Y, Wada S, Sugiyama Y, Horie T. (2012). Long-lasting inhibitory effects of cyclosporin A, but not tacrolimus, on OATP1B1- and OATP1B3mediated uptake. Drug Metab Pharmacokinet.

Smak Gregoor PJ, van Gelder T, Hesse CJ, van der Mast BJ, van Besouw NM, Weimar W. (1999). Mycophenolic acid plasma concentrations in kidney allograft recipients with or without cyclosporin: a cross-sectional study. Nephrol Dial Transplant, 14, 706-8.

Treiber A, Schneiter R, Hausler S, Stieger B. (2007). Bosentan is a substrate of human OATP1B1 and OATP1B3: inhibition of hepatic uptake as the common mechanism of its interactions with cyclosporin A, rifampicin, and sildenafil. Drug Metab Dispos, 35, $1400-7$. 
Uwai Y, Motohashi H, Tsuji Y, Ueo H, Katsura T, Inui K. (2007). Interaction and transport characteristics of mycophenolic acid and its glucuronide via human organic anion transporters hOAT1 and hOAT3. Biochem Pharmacol, 74, 161-8.

van Gelder T, Klupp J, Barten MJ, Christians U, Morris RE. (2001). Comparison of the effects of tacrolimus and cyclosporine on the pharmacokinetics of mycophenolic acid. Ther Drug Monit, 23, 119-28.

Westley IS, Brogan LR, Morris RG, Evans AM, Sallustio BC. (2006). Role of Mrp2 in the hepatic disposition of mycophenolic acid and its glucuronide metabolites: effect of cyclosporine. Drug Metab Dispos, 34, 261-6.

Wolff NA, Burckhardt BC, Burckhardt G, Oellerich M, Armstrong VW. (2007). Mycophenolic acid (MPA) and its glucuronide metabolites interact with transport systems responsible for excretion of organic anions in the basolateral membrane of the human kidney. Nephrol Dial Transplant, 22, 2497-503.

Zucker K, Rosen A, Tsaroucha A, de Faria L, Roth D, Ciancio G, Esquenazi V, Burke G, Tzakis A, Miller J. (1997). Unexpected augmentation of mycophenolic acid pharmacokinetics in renal transplant patients receiving tacrolimus and mycophenolate mofetil in combination therapy, and analogous in vitro findings. Transpl Immunol, 5, 225-32.

\section{Figure captions}

Figure 1: proposed pathways for MPA hepatic disposition and enterohepatic cycling, and mechanism for its interaction with cyclosporine. The figure is based on evidence provided by the literature (Bullingham et al., 1998, Patel et al., 2012, Picard et al., 2011, Picard et al., 2010, Uwai et al., 2007, Wolff et al., 2007) 


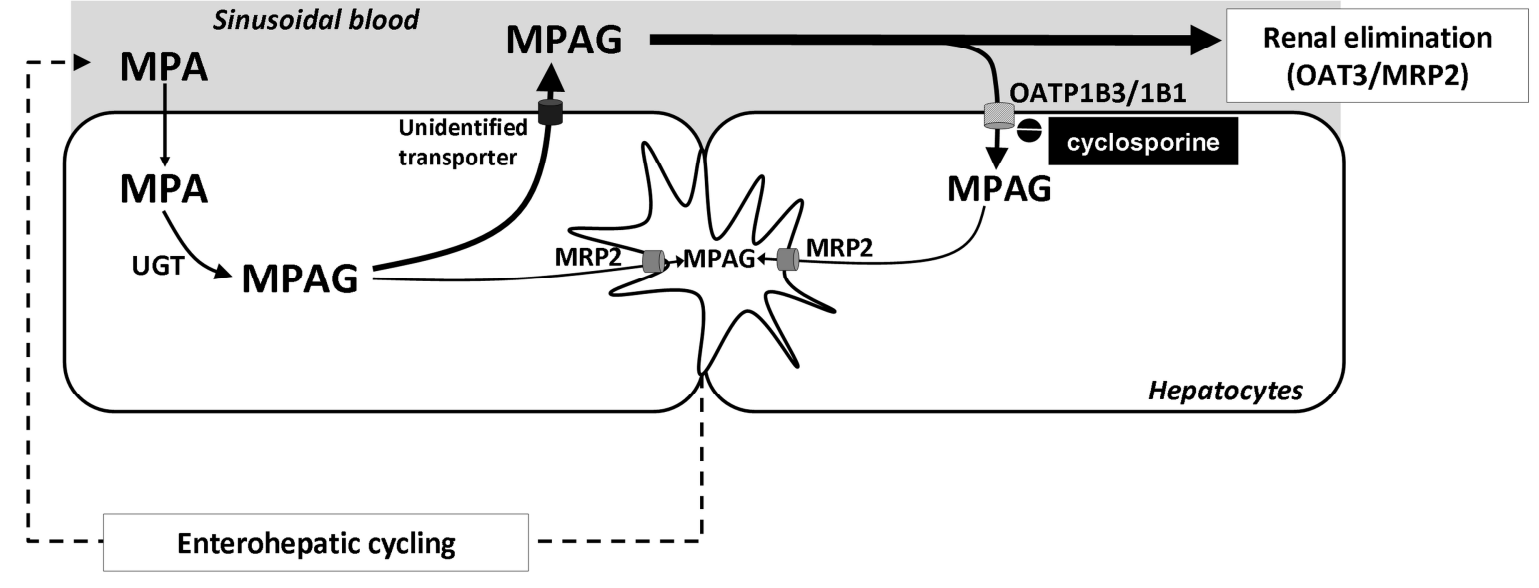

Figure 1 